\title{
Build Commitment, Leadership, the Motivation of the Performance of Coach PPLP North Sumatera
}

\author{
Jonny Siahaan \\ Dinas Pendidikan dan Olahraga Sumatera Utara \\ Medan, Indonesia \\ jonnysiahaan24@yahoo.com
}

\author{
Imran Akhmad, Indra Kasih \\ Fakultas Ilmu Keolahragaan Universitas Negeri Medan \\ Medan, Indonesia \\ imranakhmad73@gmail.com \\ indra_ksh@yahoo.com
}

\begin{abstract}
The purpose of this study intends to find scientifically accurate answers about the presence or absence of the relationship between commitment, leadership and motivation to the performance of the trainer, both directly and indirectly. This research was conducted in PPLP North Sumatra in 2018 with $\mathbf{n}=11$ all populations as samples. This study uses a survey method, with a correlational design approach through path analysis techniques (Path Analysys) which uses structural equations namely causality between exogenous and endogenous variables. With the constellation as follows: 1) Direct influence of Commitment to the Performance of Coach in the Student Training and Education Center (PPLP) of North Sumatra. 2) Direct Influence of Leadership on the Performance of coach in the Student Training and Education Center (PPLP) North Sumatra. 3) Direct Influence of Motivation on the Performance of coach in the Student Training and Education Center (PPLP) of North Sumatra. 4) Direct influence of commitment to motivation. 5) Direct influence of leadership on motivation. The results of the analysis of this study recommend that the quality of commitment, quality of leadership and quality of motivation improve the performance of PPLP coach in North Sumatra which have an impact on improving the performance of athletes..
\end{abstract}

Keywords : Commitment, Leadership, Motivation and Performance.

\section{INTRODUCTION}

Law No. 3 of 2005 concerning the National Sports System in article 27 paragraph 5 states that "the development and development of sports achievements is carried out by involving potential young sportsmen from the results of monitoring, guiding and developing talent as a regeneration process". In supporting the mandate of the Law, one of the efforts made by the regional government is the establishment of a Student Training and Training Center (PPLP) for North Sumatra students located in 15 State Senior High Schools in Medan Sunggal sub-district in Medan that built in 1984.

The results of the research survey show the achievements of North Sumatra in the last three years at the National Sports Week (POPNAS) can be seen in the following table :
TABLE 1. North Sumatra Achievements for the Last 3 Years

\begin{tabular}{|c|c|c|c|c|c|c|}
\hline \multirow[b]{2}{*}{$\begin{array}{l}\mathbf{N} \\
\mathbf{0}\end{array}$} & \multirow{2}{*}{$\begin{array}{c}\text { Event-Event } \\
\text { Nasional }\end{array}$} & \multirow{2}{*}{$\begin{array}{l}\text { Perin } \\
\text { gkat }\end{array}$} & \multicolumn{3}{|c|}{ Mendali } & \multirow{2}{*}{$\begin{array}{c}\text { Jumlah } \\
\text { Atlit }\end{array}$} \\
\hline & & & $\begin{array}{c}\text { Ema } \\
\mathrm{s}\end{array}$ & Perak & $\begin{array}{c}\text { Perung } \\
\text { gu }\end{array}$ & \\
\hline 1 & $\begin{array}{c}\text { POPNAS ke XII } \\
\text { tahun } 2013 \mathrm{di} \\
\text { Jakarta }\end{array}$ & 12 & 8 & 8 & 11 & 174 \\
\hline 2 & $\begin{array}{c}\text { POPNAS ke XIII } \\
\text { tahun } 2015 \text { di } \\
\text { Bandung Jawa } \\
\text { Barat } \\
\end{array}$ & 14 & 1 & 5 & 2 & 152 \\
\hline 3 & $\begin{array}{c}\text { POPNAS ke XIV } \\
\text { tahun } 2017 \text { di } \\
\text { Semarang Jawa } \\
\text { Tengah }\end{array}$ & 11 & 4 & 10 & 16 & 172 \\
\hline
\end{tabular}

(Sumber : Data Dispora Sumut)

The decline in student sports performance in North Sumatra is inseparable from problems at the Student Training and Training Center (PPLP) of North Sumatra. From the results of a survey conducted by researchers at the Student Training and Training Center (PPLP) of North Sumatra, the researchers argue that several components that are directly related to the implementation of the Student Training and Training Center (PPLP) include Human Resources (athletes, trainers and administrators), facilities and infrastructure, funding, management, recruitment systems, and dietary systems (nutrition).

Various problems related to the weaknesses of the Student Training and Training Center (PPLP) of North Sumatra were found, including; Human Resource Problems (athletes, trainers and administrators), facilities and infrastructure problems, management, recruitment problems, dietary system problems (nutrition), and aspects of sportsman ability related to this personality factor have not been touched.

The researcher argues based on the above problems, one of the very digital problems in the training process in addition to the factors within the student / athlete is also important which is also a factor of self-coach

There were various problems related to the weaknesses of the Student Training and Training Center (PPLP) of North Sumatra, including one of them was the Human Resources Problem (athletes, Trainers and administrators), this was 
related to the quality and quantity of the HR of the Student Training and Training Center (PPLP ) North Sumatra. Trainers who are not yet fully committed, trainers who have not implemented training programs, leadership coaches who have not reflected a trainer and trainer who are just just to attend attendance as well as additional income that is just a responsibility to their duties.

The researchers suspect, other factors that influence the performance of the trainer are the factors that determine the performance of the trainer of the Student Training and Training Center (PPLP) of North Sumatra is the perception of the coach's commitment, leadership and motivation.

\section{THEORETICAL STUDY.}

\section{Coach}

According to Brooks and Fahey (1984) suggests that coaches have the task as planners, leaders, friends, mentors, and controllers of training programs. Meanwhile the athlete has the task of doing the exercises according to the coach's predetermined program. The trainer is able to play a role in improving the quality of the performance of athletes by using effective training methods.

So according to the writer that a coach should really do the coaching in this case train, and a principal coach must be a planner, leader, friend, mentor, and exercise program controller.

\section{Commitmen}

Commitments according to Gary Dessler (2003: 3) 'relate to aspects of one's personality that are manifested in behavior. With a commitment someone will state a determination to do something. Dessler stated that commitment is the identification of workers and states to achieve the company's mission '.

According to Mathieu and Zagac in Luthan (1995: 321322) revealed that "commitment will provide positive support for the results expected by the organization such as for performance, avoiding workers to stop and absence of work". Furthermore, organizational commitment is defined by Robbins (2003: 190) 'as a situation where a member siding with an organization and its goals, and interested in maintaining membership in the organization'.

The author concludes that commitment is a statement of a person to devote himself in carrying out the task on behalf of the organization with the intention of achieving the desired goal. The trainer's commitment to the Regional Student Education and Training Center (PPLPD) / Student Training and Education Center (PPLP) of North Sumatra is a commitment that the trainer has to carry out his daily tasks seriously with the top five types of categories for sportsmen, organizations, themselves, people other and assignments.

\section{Leadership}

Leadership in English is called the leader from the word to lead, the exercise is called leadership. Keith in Guterres and
Supartha (2016: 431) means that "leadership is the ability of a person to know others in achieving goals and enthusiasm".

Whereas Semueil (2011: 89) explained that "leadership is the ability to empower subordinates / members so that initiatives arise to be creative in work and the results are more meaningful for the organization with leaders sometimes directing, mobilizing, and influencing members".

So it can be concluded that coach leadership has a very important role in influencing athletes to carry out training well and according to the goals that have been set.

\section{Motivation}

In the opinion of Lefton (1982: 143) "Motivation is a specific internal condition and directs one's behavior to a goal". A training process, increasing self-motivation is very important, both the trainer's self-motivation and the athlete itself.

According to Robbins in Juniantara (2015: 14) "motivation is a satisfying way to meet the needs of an employee which means that when a person's needs are met by certain factors, the person will exert the best effort to achieve organizational goals". Thus motivation can also be interpreted as an effort to change behavior towards a better direction with the goals set by the organization.

Based on that, the trainer's motivation can be explained in the following indicators; (1) responsibility, (2) competition, (3) the spirit of practice, (4) resilient against obstacles, (5) displaying the best, (6) minimizing errors, (7) not repeating the same mistakes.

\section{Coach Performance}

Job satisfaction shows more on the behavior of the behavior, because in the opinion of Robbins and Judge (2009: 65) that 'job satisfaction: a positive feeling about one job resulting from an evaluation of it characteristics'. Some definitions put forward by experts are as follows: 'Job satisfaction is an attitude that individuals have about their jobs. It results from their perception of their job, based on factors of the work environment, such as the supervisor's style, policies and procedures, work group affiliation, working condition, and fringe benefit' (Gibson et al., 1997:75).

Opinions from Bernardin and Russell (1993: 379) suggest that "Performance is the record of outcome produced on a specified job function or activity during a specified time period". This is further clarified by Bowin and Harvey (1996: 140) who say "Performance may be defined as the accomplishment of an employee or manager assigned duties and the outcomes produced on a job function or activity during specified time period". Furthermore, Colquitt, Lepine and Wasson (2009: 104) argue that kerja job satisfaction is an expression of feeling happy about the assessment of a job or work experience'.

A description of the theories that have been proposed, it can be synthesized that the performance referred to in this study is a statement of feeling of pleasure or dislike of the coach towards various aspects of the work that is his 
responsibility reflected through assignments, promotions, salaries, awards, co-workers, and relationships with a boss

\section{METHODOLOGY}

\section{Research purposes}

The purpose of this study intends to find out about the presence or absence of the relationship between commitment (X1), leadership (X2) and motivation (X3) to the performance of trainers at the Student Training and Education Center North Sumatra (X4) both directly or indirectly. The operational purpose of this research is to find out:

1. Direct influence of Commitment (X1) to the Performance of Trainers (X4) Student Training and Education Center (PPLP) North Sumatra.

2. Direct Influence of Leadership (X2) on the Performance of Trainers (X4) Student Education and Training Centers (PPLP) North Sumatra.

3. Direct influence of Motivation (X3) on the Performance of Trainers (X4) Student Training and Education Center (PPLP) North Sumatra.

4. Direct influence of Commitment (X1) to Motivation (X3).

5. Direct influence of Leadership (X2) on Motivation (X3).

6. Is there any influence of commitment (X1) on the performance of the coach (X4) of the Student Training and Training Center (PPLP) of North Sumatra through motivation (X3).

7. Is there an influence of leadership (X2) on the performance of the coach (X3) of the Student Training and Training Center (PPLP) of North Sumatra through motivation (X3).

\section{Research Methods}

This research method uses a survey method, with a correlational design approach through path analysis techniques (Path Analysys) which uses a structural equation namely causality between exogenous and endogenous variables. Path analysis technique is used to test the amount of contribution (contribution) shown by the path coefficients in each path diagram of the causal relationship between variables. Correlation and regression analysis which is the basis of the calculation of the path coefficient.

This study involves 3 exogenous variables that will be studied to influence the endogenous variables. Exogenous variables include commitment (X1), leadership (X2) and commitment (X3), endogenous variables namely coach performance (X4). The linkages between variables in this study in Figure 1 in the constellation are as follows:

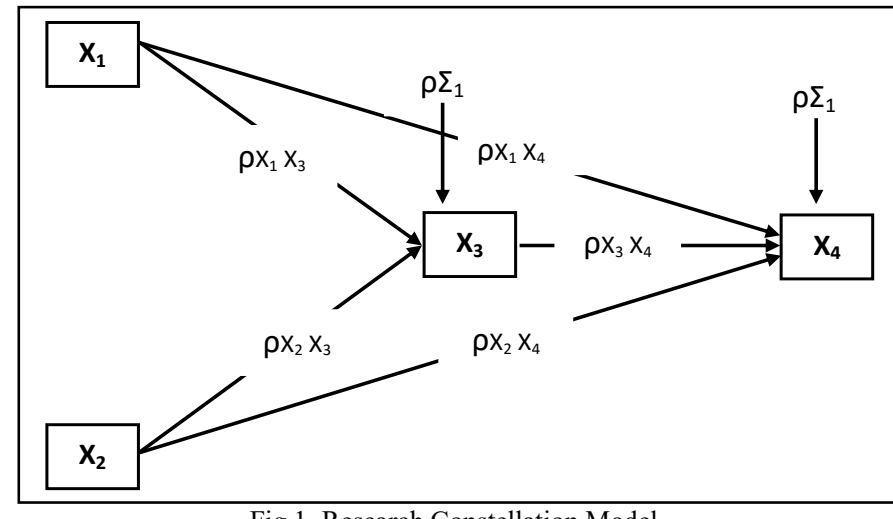

Information:

$\rho X_{1} \rho X_{4}=$ Intermediate path coefficient $X_{1}$ dengan $X_{4}$

$\rho X_{2} \rho X_{4} \quad=$ Intermediate path coefficient $X_{2}$ dengan $X_{4}$

$\rho X_{3} \rho X_{4} \quad=$ Intermediate path coefficient $X_{3}$ dengan $X_{4}$

$\rho X_{1} \rho X_{3} \quad=$ Intermediate path coefficient $X_{1}$ dengan $X_{3}$

$\rho X_{2} \rho X_{3}=$ Intermediate path coefficient $X_{2}$ dengan $X_{3}$

$\rho X_{1,3} \rho X_{4}=$ Intermediate path coefficient residual $X_{1}, X_{3}$ with $\mathrm{X}_{3}$

$\rho X_{2,3} \rho X_{4} \quad=$ Path coefficient for residuals $X_{2}, X_{3}$ with $X_{4}$

The sample in this study is by using total sampling technique. The number of samples in this study were 11 trainers.

Analysis of research data was carried out with descriptive statistics and inferential statistics. Descriptive statistics the aim is to obtain an overview of the score distribution characteristics of each variable examined by means of calculation, standard deviation, median and mode. Inferential statistics are used to test hypotheses using simple regression and correlation analysis techniques and multiple regression analysis and correlation techniques. Before the hypothesis test, the analysis requirements are first tested.

\section{RESEARCH RESULT}

The results of this study can be concluded that; (1) Directly the commitment influences the performance of the trainer with a percentage contribution of $22.17 \%$, (2) Directly the leadership influences the performance of the trainer with a percentage of contribution of $50.5 \%$, (3) directly motivation influences the performance of the trainer with a percentage contribution of $15.21 \%$, (4) directly the commitment influences motivation with the percentage contribution of $1.91 \%$, (5) directly the leadership influences motivation with the percentage contribution of $3.72 \%$, , (6) indirectly commitment to the performance of the coach through motivation with a percentage contribution $11.29 \%$, (7) indirectly leadership on the trainer's performance through motivation with a percentage contribution of $9.58 \%$. 


\section{CONCLUSIONS}

The implication of this study, that the influence of leadership has the largest contribution is $50.5 \%$. this shows that to improve the performance of the trainer, the leadership of the dominant stance, in other words that in order to produce good coach performance satisfaction, first the commitment and motivation must be increased. Commitment to coach performance has the next biggest contribution, in other words that this variable also determines the satisfaction of the coach's performance. While achievement motivation occupies the lowest contribution of both variables. It does not mean that motivation has the worst contribution, but the importance of the role of the coach in motivating sportsmen to remain committed to achieving the highest achievement.

Besides that, increasing commitment can be optimal in improving coach performance when motivation is increased first. Likewise, further that to improve the performance of the trainer, the leadership must also be to improve the performance of the coach so that leadership must also be enhanced through motivation.

\section{REFERENCES}

[1] Anon, Undang-undang Republik Indonesia Nomor 3 tahun 2005 tentang sistem Keolahragaan Nasional, (RI: Kementerian Negara Pemuda dan Olahraga, 2005), h.21.

[2] Brooks G. A., and T. D. Fahey. 1985. Exercise Physiology: Human Bioenergetics and Its applications. New York : Macmillian Publishing Co. p. 322-323, 330-331, 334, 313.

[3] Gary Dessler, Human Resource Management, 9th Ed. (Singapore: Prentice Hall Pearson Education, Inc, 2003), h. 3.

[4] Luthans, Fred. Organizational Behavior, $11^{\text {th }}$ ed. (New York: McGrawHill-Irwin, 2008), hh. 231-232.

[5] Robbins, Stephen P. Organizational Behavior, $10^{\text {th }}$ edition.(Englewood Cliff: Prentice Hall,2003), h. 190.

[6] Guterres, A. Luis. \& Supartha, G. Wayan. 2016. Pengaruh Gaya Kepemimpinan dan Motivasi Kerja Terhadap Kinerja Guru. Jurnal Ekonomi dan Bisnis Universitas Udayana 5.3, Hal.429-454.

[7] Semueil, W. I. 2011.Hubungan Gaya Kepemimpinan Kepala Sekolah dengan Motivasi Kerja Guru SMK Negeri Manado. Jurnal Pendidikan dan Kejuruan. Vol. 2, No. 2, Hal. 83-97.

[8] Lefton, Lester A. dan Laura Valvatne. 1982. Mastering Psychology. Boston: Allyn and Bacon.

[9] Robbins, Stephen P dan Timothy A. Judge. Organizational Behavior. (New York:Upper Saddle River,2009), h. 65.

[10] Gibson, James L., John M. Ivancevich, and James, H. Donnelly. 1997. Organisasi, Perilaku, Struktur, Proses. Edisi Kedelapan, Terjemahan. Jakarta: Binarupa Aksara, h. 75.

[11] Bernardin, H. John, and Joyce, E.A. Russel, 1993. Human Resource Management An Experiential Approach. New York: McGraw-Hill. Series In Management. H. 379.

[12] Bowin, Robert Bruce, and Don, Harvey, 1996. Human Resource Management An Experiential Approach. London: Prentice-Hall International, Inc.h. 140 .

[13] Colquitt, Jason. A. Jeffery A. Lepine and Michael wasson, Organizational Behavior (New York: McGraw-Hill Company, h. 104. 